\title{
Autoradiographic study of the effect of actinomycin D on decidual differentiation of stromal cells in the mouse uterus
}

\author{
C. A. Finn and J. C. S. Bredl \\ Department of Physiology, The Royal Veterinary College, London NW1 0TU, U.K.
}

The administration of actinomycin $\mathrm{D}$ to pregnant mice before the zygote has started to implant does not prevent the early stages of the implantation reaction but does delay, for a period of about $30 \mathrm{~h}$, differentiation of the endometrial stromal cells into decidual cells (Finn \& Martin, 1972; Finn \& Bredl, 1973). During the period of delay vascular permeability is increased and oedema fluid collects in the stroma. An inhibitory effect of actinomycin $\mathrm{D}$ on decidualization has also been demonstrated in the rat (Burin \& Sartor, 1965; Sananès \& Psychoyos, 1970).

The finding that stromal differentiation is halted for about $30 \mathrm{~h}$ and then continues, presumably after the effect of the drug has worn off, is surprising. In normal pregnancy in mice the stromal cells proliferate in response to ovarian hormones during the $24 \mathrm{~h}$ preceding attachment of the blastocyst (Finn \& Martin, 1967). After attachment the stromal cells surrounding the blastocyst decidualize whilst the more peripheral stromal cells are stimulated to divide and subsequently to decidualize. The delay of decidualization after administration of actinomycin $\mathrm{D}$ could be due to death of those cells which should have become the first decidual cells, the subsequent onset of decidualization therefore being due to differentiation of cells unaffected by the treatment. Another possibility is that the drug does not kill the stromal cells, but blocks the progress of differentiation so that transformation of the cells can proceed after they are released from the effects of the drug.

To differentiate between these two suggestions, the uterine stromal cells of mice were labelled with tritiated thymidine during the period of hormone-induced mitosis and the fate of the labelled cells during decidualization was followed.

\section{Methods and results}

Randomly bred albino mice were kept under conditions of controlled heating and lighting with an $8 \mathrm{~h}$ dark period ending at $12.00 \mathrm{~h}$.

Experiment 1 . Thirty cyclic females, approximately 2 months old, were ovariectomized under tribromoethanol anaesthesia about 1 week before the start of hormone treatment. Hormones were administered subcutaneously in $0.05 \mathrm{ml}$ vehicle according to the following schedule: Days 1-3, $100 \mathrm{ng}$ oestradiol-17 $\beta$ (Organon Laboratories); Day 6, $1 \mathrm{mg}$ medroxyprogesterone acetate (Provera: Upjohn Ltd); Day 7, 10 ng oestradiol-17ß; Day 8, $30 \mu \mathrm{Ci}\left[{ }^{3} \mathrm{H}\right]$ thymidine (Radiochemical Centre, Amersham: sp. act. $20 \mathrm{Ci} / \mathrm{mmol}$ ) (in $0.1 \mathrm{ml}$ water by intraperitoneal injection) followed $1 \frac{1}{2} \mathrm{~h}$ later by $10 \mathrm{ng}$ oestradiol-17 $\beta$. After the oestradiol injection on Day 8, the experimental animals received $15 \mu \mathrm{g}$ actinomycin D (Merck Sharp \& Dohme) (in $0.1 \mathrm{ml}$ water by intraperitoneal injection) at $4 \mathrm{~h}$ and all the animals received a decidual stimulus at $6 \mathrm{~h}$. Groups of 5 actinomycin D-treated and 5 control animals were killed 24,48 and $72 \mathrm{~h}$ after the application of the decidual stimulus, which consisted of an injection of $0.01 \mathrm{ml}$ arachis oil injected into the lumen of the left horn of the uterus. One piece from each uterine horn was fixed in Bouin's fluid and embedded in paraffin wax. Sections were cut at $5 \mu \mathrm{m}$ and processed for autoradiography using the dipping film technique (Ilford K5 emulsion and D19b developer). The slides were stored for 3 weeks before development and after processing counterstained lightly with haematoxylin and eosin. Labelled cells were easily identified by the high density of silver grains over the nuclei.

The extent and timing of the decidual response resembled that found in earlier experiments (Finn \& Martin, 1972). In the actinomycin D-treated animals there was very little decidual response 
at $48 \mathrm{~h}$ but a fairly extensive reaction by $72 \mathrm{~h}$, the response at this time approximately resembling that found in the control animals at $48 \mathrm{~h}$.

At 24 and $48 \mathrm{~h}$, the control animals showed large numbers of labelled cells throughout the stroma (Table 1), with greatest frequency towards the lumen. Large numbers of decidualized cells were labelled. By $72 \mathrm{~h}$ there were fewer labelled cells and these were mostly in the primary decidual zone around the antimesometrial end of the lumen, the area in which the implantation chamber forms (Finn \& Porter, 1975).

Table 1. Frequency of thymidine-labelled cells (mean \pm S.E.M.) in the mouse endometrium (stroma) at various times after the application of a decidual stimulus to the left horn

\begin{tabular}{|c|c|c|c|c|c|}
\hline \multirow[b]{2}{*}{ Group } & \multirow[b]{2}{*}{ Treatment } & \multirow[b]{2}{*}{ Horn } & \multicolumn{3}{|c|}{ Time after stimulus } \\
\hline & & & $24 \mathrm{~h}$ & $48 \mathrm{~h}$ & $72 \mathrm{~h}$ \\
\hline 1 & Actinomycin D & $\begin{array}{l}\text { Left } \\
\text { Right }\end{array}$ & $\begin{array}{l}226 \pm 14 \cdot 6 \\
159 \pm 14 \cdot 4\end{array}$ & $\begin{array}{r}172 \pm 41.0 \\
89 \pm 9.7\end{array}$ & $\begin{array}{r}242 \pm 25 \cdot 0 \\
59 \pm 11 \cdot 4\end{array}$ \\
\hline 2 & Control & $\begin{array}{l}\text { Left } \\
\text { Right }\end{array}$ & $\begin{array}{l}170 \pm 15.6 \\
165 \pm 51.0\end{array}$ & $\begin{array}{l}245 \pm 34.4 \\
110 \pm 20.7\end{array}$ & $\begin{array}{r}108 \pm 23.8 \\
85 \pm 11.9\end{array}$ \\
\hline
\end{tabular}

One randomly selected cross-section of uterine horn was counted from each of the 5 mice/group.

In the experimental animals the number of labelled cells at $72 \mathrm{~h}$ was similar to that of the control animals at $48 \mathrm{~h}$ and many of the decidual cells were labelled.

In the treated and control animals there was a reduction in the number of labelled stromal cells with time in the right (unstimulated) horns (Table 1). This was especially marked in the actinomycin D-treated animals, in which there was also a general shortage of all stromal cells.

Experiment 2. Twenty-five mice were mated, the day on which the vaginal plug was found being called Day 1 of pregnancy. All the animals were ovariectomized on Day 4 and treated s.c. with $1 \mathrm{mg}$ medroxyprogesterone acetate to counteract the adverse effect of actinomycin $\mathbf{D}$ on the secretion of progesterone by the corpus luteum and to control the timing of implantation with more precision. At $20 \mathrm{~min}$ and $6 \mathrm{~h} 20 \mathrm{~min}$ after ovariectomy, $30 \mu \mathrm{Ci}\left[{ }^{3} \mathrm{H}\right]$ thymidine were injected i.p. On Day 5 the mice were injected i.p. with $15 \mu \mathrm{g}$ actinomycin $\mathrm{D}$ in water or with water only, and $2 \mathrm{~h}$ later all the animals were given $20 \mathrm{ng}$ oestradiol-17 $\beta$ s.c. to induce implantation. Groups of 4 (or 5) mice were killed 24,48 or $72 \mathrm{~h}$ later, and segments of uteri processed for autoradiography as described above.

As in the earlier experiments (Finn \& Bredl, 1973 and Exp. 1) actinomycin D delayed decidualization so that the uteri of the $72 \mathrm{~h}$ treated animals resembled those of the controls at $48 \mathrm{~h}$. Because of the double injection of thymidine, labelling was higher than in Exp. 1, and accurate counting was extremely difficult. However, confirmation that labelled cells were present in the decidua in large numbers was readily obtained by examination of the actinomycin D-treated animals killed at $72 \mathrm{~h}$; in the heavily decidualized area around the blastocyst counts of several hundred labelled cells were found in all animals (P1. 1, Figs 1 and 2).

\section{Discussion}

The results from both experiments indicate that the proliferating stromal cells which were undergoing DNA replication at the time when the labelled thymidine was injected contribute to the differentiated decidua, confirming the earlier finding in the rat by Galassi (1968). Although the formation of the decidua was delayed in the animals treated with actinomycin $D$, there was no reduction in the number of labelled cells participating in the eventual decidual differentiation. This was in contrast to the situation in the right horn (Exp. 1) in which there was no decidualization and a marked decline in the number of labelled cells between 24 and $72 \mathrm{~h}$, particularly in the treated animals. The presence of pyknotic nuclei among the cells suggests that considerable cell death had taken place in this horn, presumably of the stromal cells produced by proliferation on Day 4 of pregnancy but not stimulated 
PLATE 1
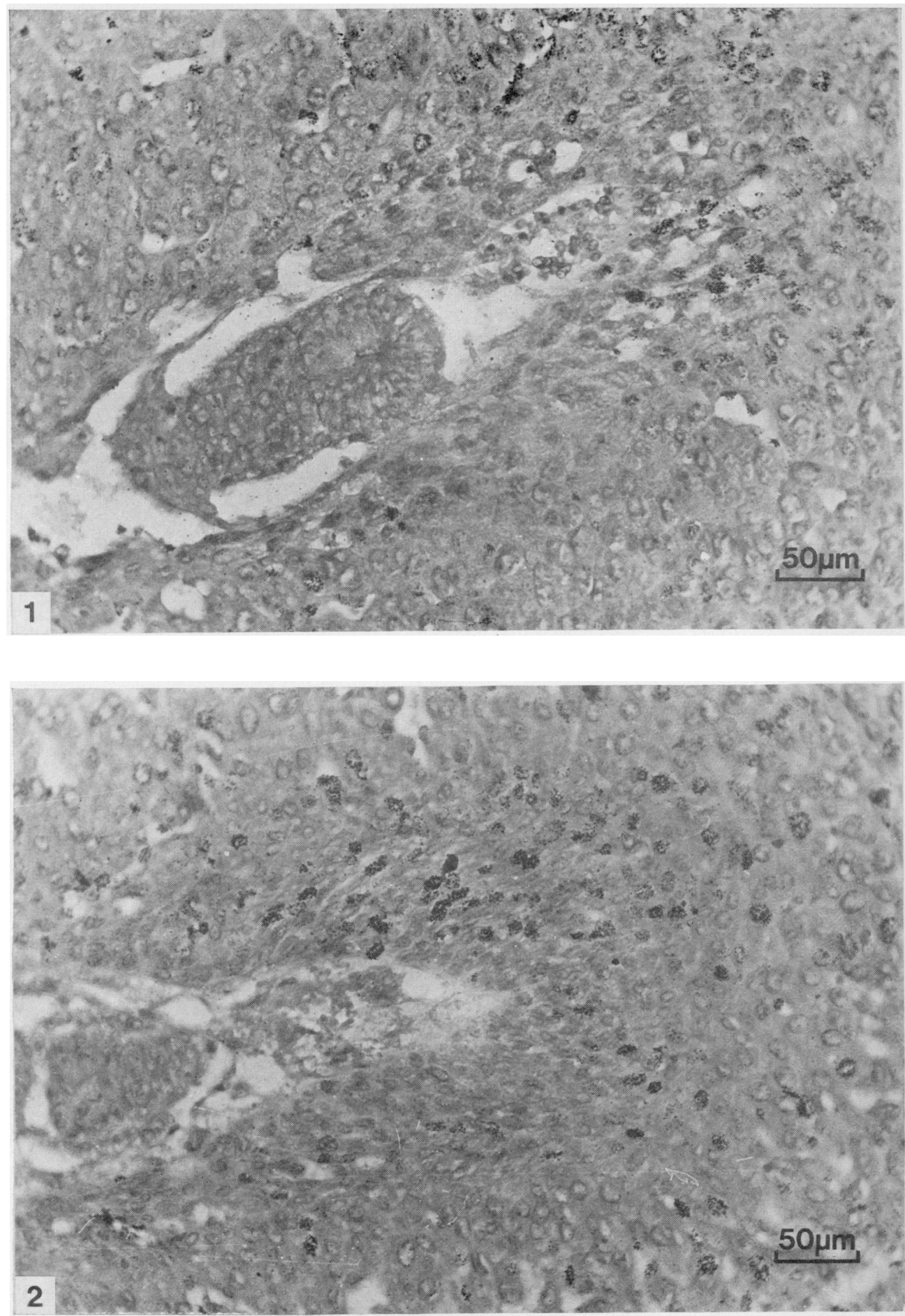

Fig. 1. Cross-section through the implantation chamber of a control mouse killed $48 \mathrm{~h}$ after the induction of implantation. Many labelled cells can be seen in the stroma.

Fig. 2. Similar section from an actinomycin D-treated mouse killed $72 \mathrm{~h}$ after the induction of implantation.

Labelled cells are clearly visible in the stroma. 
to differentiate into decidual cells. This finding will need further investigation, but the reduction in the number of labelled cells in the non-decidualizing horns highlights the constancy of numbers in the decidualizing horns.

From these results it is clear that the delay of decidualization caused by the administration of actinomycin $\mathrm{D}$ cannot be attributed to the death of cells destined to decidualize. It is therefore likely that the drug in some way reversibly blocks the progress of differentiation by interfering with some essential process within the cell. From what is known of the mode of action of actinomycin D in other situations it is probable that the block occurs in the transcription of information contained within the genome.

\section{References}

Burnn, P. \& SARToR, P. (1965) Inhibition de la réaction déciduale par l'actinomycine D. C.r. Séanc. Soc. Biol. 159, 141-144.

FINN, C.A. \& BredL, J.C.S. (1973) Studies on the development of the implantation reaction in the mouse uterus: influence of actinomycin D. J. Reprod. Fert. 34, 247-253.

FinN, C.A. \& Martin, L. (1967) Patterns of cell division in the mouse uterus during pregnancy. J. Endocr. 39, 593-597.

FInN, C.A. \& MARTIN, L. (1972) Temporary interruption of the morphogenesis of deciduomata in the mouse uterus by actinomycin D. J. Reprod. Fert. 31, 353358.

Finn, C.A. \& Porter, D.G. (1975) The Uterus. Paul Elek, London.

Galassi, L. (1968) Autoradiographic study of the decidual cell reaction in the rat. Devl Biol. 17, 75-84.

Sananès, N. \& Psychoyos, A. (1970) Effet de l'actinomycin-D sur le développement du déciduome chez la ratte. C. r. hebd. Séanc. Acad. Sci., Paris 271, 430-433.

Received 17 September 1976 